\title{
A Review of Factors Affecting the Growth of Small and Medium Enterprises (SMEs) in Tanzania
}

\author{
Jesca Mhoja Nkwabi* $\quad$ Leodger B. Mboya \\ Doctoral candidate of the University of the West of Scotland (UWS), School of Business and Creative \\ Industries, 235 Southwark Bridge Rd, London SE1 6NP
}

\begin{abstract}
The growth of Small and Medium Enterprises (SMEs) globally is dependent upon a conducive business environment. However, in Tanzania, SMEs face several constraints such as limited finances, poor market accessibility, low entrepreneurial knowledge and bureaucracy which hinders their growth. This paper aims to assess the factors impeding the growth of SMEs in Tanzania. Factors such as a lack of business training, capital constraints, a lack of finance, poor infrastructure, a lack of collateral, poor production, poor technologies, tight regulations, corruption, poor market accessibility, the motivation of the business owners, limited access to information, a lack of human competencies and inadequate raw materials were measured. A mixed-method approach was used in this study, inclusive of content analysis to extract the constraints from the 21 items of literature in Tanzania. Thereafter, a quantitative approach was applied where descriptive statistics were used to determine the frequency and percentage of the factors in order to extract the most significant variables affecting SME growth in Tanzania. The findings reveal that Tanzanian SME growth is mostly impacted by financial constraints, capital constraints, poor technology and tight regulations. The study recommends that financial assistance through lowering the interest rates and simplifying the borrowing procedures must be given to SMEs to enable them to avail the necessary finance and capital for their business Also the government must support SMEs by simplifying the regulations for SMEs such as levying taxes. Business training must be provided to the SMEs by government organisation such as the Small Industries Development Organisation (SIDO) to facilitate business knowledge.
\end{abstract}

Keywords: SME, challenges, growth.

DOI: $10.7176 / \mathrm{EJBM} / 11-33-01$

Publication date: November $30^{\text {th }} 2019$

\section{Introduction}

The Tanzanian SME sector has been recognised as a critical sector in the creation of employment opportunities, the generation of income and in its contribution to GDP and economic growth. It is estimated that there are over 3 million SMEs in Tanzania that are engaged in various businesses such as manufacturing, retail and trade, agricultural and services (Mashenene \& Rumanyika, 2014). In Tanzania, small scale businesses are defined according to the number of employees and capital invested in machinery. Therefore a micro-enterprise comprises of up to 5 people with a minimum capital requirement of up to 5 million Tanzanian Shillings (TZS), a small enterprise comprises of 5-49 employees with a minimum capital of 5-200 million (TZS) and a medium-scale enterprise comprises up to 100 employees with a minimum capital of 200-800 employees. In 2003, the government introduced the SME development policy that was aimed at alleviating poverty and improving the SME sector. The same policy was reviewed in 2013 which documented that despite the government efforts to improve the sector, SMEs still are faced with challenges such as a failure to compete in international markets, financial constraints, underproduction, poor supply chain management, technological difficulties, a lack of access to raw materials and a low business registration rate. Despite an attempt by previous researchers (Mashenene \& Rumanyika, 2014; Kimathi, 2015; Anderson, 2017) to document SME constraints, these issues still persist and as a result, SMEs still undergo challenges which force most of them to go out of business. An explanation of such persistence that can be given is that the country has limited resources and so addressing most of the challenges can prove to be difficult. This research, therefore, aims to evaluate the critical impediments hindering SME growth in order to provide feasible solutions on how these challenges can be tackled to facilitate SME growth.

\section{Literature review}

Business impediments have been recognised as stumbling blocks standing in the way of SME growth around the globe. Mashenene \& Rumanyika (2014) reported inadequate business training, insufficient capital and an antientrepreneurial culture to be the major constraints affecting SMEs in Tanzania. Bilal, Khan \& Akoorie's (2016) study on South Asian countries reported financial constraints to be the major impediment affecting SMEs in Pakistan and India. The same was reported by Wang (2016), who found external financing to be a major constraint to growth in SMEs in developing nations. Bouazza, Ardjouman \& Abada (2015) reported the business environmental factors, legal and regulatory frameworks, access to external financing and human resource capacities to be the major constraints affecting Algerian SMEs. Baporikar, Nambira \& Gomxos (2016) found that 
Namibian SMEs are unable to grow due to factors such as stealing and security problems from their customers, a failure to adapt to the latest technology, access to finance, appropriate marketing strategies and a lack of skilled manpower. Yukhanaev et al. (2015) found that Russian SMEs face political, economic and regulatory challenges which hinder their growth. Clegg (2018) reported a lack of people-based capability, a lack of competence, a lack of skills and information technology to be the central factors hindering SME growth in the UK.

\subsection{Selected studies on SME growth constraints in the Tanzanian Context}

Table 1 Selected SME studies from Tanzania

\begin{tabular}{|c|c|c|c|}
\hline S/NO & Title & Authors & $\begin{array}{l}\text { Major findings (Constraints facing } \\
\text { SMEs) }\end{array}$ \\
\hline 1. & $\begin{array}{l}\text { Business Constraints and the } \\
\text { Potential Growth of Small and } \\
\text { Medium Enterprises in Tanzania: } \\
\text { A Review }\end{array}$ & $\begin{array}{l}\text { (Mashenene \& } \\
\text { Rumanyika, 2014) }\end{array}$ & $\begin{array}{l}\text { Insufficient business training, capital } \\
\text { constraints and an anti-entrepreneurial } \\
\text { culture }\end{array}$ \\
\hline 2. & $\begin{array}{l}\text { The role of microfinance in } \\
\text { promoting small and medium } \\
\text { enterprises (SMEs) in Tanzania: } \\
\text { empirical evidence from SME } \\
\text { holders who have received } \\
\text { microcredit from financial } \\
\text { institutions in Morogoro }\end{array}$ & (Makorere, 2014) & $\begin{array}{l}\text { Lack of capital, lack of access to finance, } \\
\text { inadequate business training, poor demand } \\
\text { for products, lack of raw materials and poor } \\
\text { infrastructure. }\end{array}$ \\
\hline 3. & $\begin{array}{l}\text { Socio-Cultural Determinants and } \\
\text { Enterprise Financial Sources } \\
\text { among the Chagga and Sukuma } \\
\text { Small and Medium Enterprises in } \\
\text { Tanzania }\end{array}$ & $\begin{array}{l}\text { (Mashenene, } \\
\text { Macha, \& Donge, } \\
\text { 2014) }\end{array}$ & $\begin{array}{l}\text { Poor partnership, capital constraints, lack } \\
\text { of funding, lack of collateral. }\end{array}$ \\
\hline 4. & $\begin{array}{l}\text { Non-financial constraints to } \\
\text { scaling-up small and medium- } \\
\text { sized energy enterprises: Findings } \\
\text { from field research in Ghana, } \\
\text { Senegal, Tanzania and Zambia }\end{array}$ & $\begin{array}{l}\text { (Haselip, Desgain } \\
\& \quad \text { Mackenzie, } \\
2015)\end{array}$ & Inadequate human capacity. \\
\hline 5. & $\begin{array}{l}\text { Constraints of Accessing Debt } \\
\text { Financing from Commercial } \\
\text { Banks among Small and Medium } \\
\text { Enterprises in Tanzania: } \\
\text { A Literature Review }\end{array}$ & $\begin{array}{l}\text { (Mashenene, } \\
\text { 2015) }\end{array}$ & $\begin{array}{l}\text { Poor access to debt finance, lack of } \\
\text { collateral, bureaucratic loan procedures, } \\
\text { business informality, poor repayment } \\
\text { habits and corruption. }\end{array}$ \\
\hline 6. & $\begin{array}{l}\text { Obstacles Towards Adoption of } \\
\text { Mobile Banking In Tanzania: A } \\
\text { Review }\end{array}$ & $\begin{array}{l}\text { (Rumanyika, } \\
\text { 2015) }\end{array}$ & $\begin{array}{l}\text { Poor network coverage, lack of knowledge } \\
\text { of m-banking users, lack of enough float of } \\
\text { mobile money agents and ATM breakdown } \\
\text { and theft. }\end{array}$ \\
\hline 7. & $\begin{array}{l}\text { The Challenges Confronting Small } \\
\text { Scale Businesses in accessing } \\
\text { Microfinance Services from MFIs } \\
\text { Case Study: Rural Tanzania }\end{array}$ & (Kimathi, 2015) & Lack of access to finance. \\
\hline 8. & $\begin{array}{l}\text { Examining the Factors Affecting } \\
\text { Export Performance for Small and } \\
\text { Medium Enterprises (SMEs) in } \\
\text { Tanzania }\end{array}$ & (Mpunga, 2016) & $\begin{array}{l}\text { Export competencies, inadequate and } \\
\text { unstable financial capital, poor production, } \\
\text { poor technology, ICT and information, the } \\
\text { standard of the products produced by the } \\
\text { SME and complicated business } \\
\text { laws/regulations. }\end{array}$ \\
\hline 9. & $\begin{array}{l}\text { Factors Influencing Business } \\
\text { Succession Planning among SMEs } \\
\text { in T Tanzania }\end{array}$ & (Magasi, 2016) & Lack of business successors. \\
\hline 10 & $\begin{array}{l}\text { Challenges Facing Food } \\
\text { Processing MSEs in Tanzania: A } \\
\text { Qualitative Case Study of the } \\
\text { Sunflower Oil Industry in Babati, } \\
\text { Manyara }\end{array}$ & (Ekblom, 2016) & $\begin{array}{l}\text { Lack of capital, lack of raw materials, } \\
\text { equipment \& electricity for processing, } \\
\text { tight regulations, poor market accessibility, } \\
\text { and competition. }\end{array}$ \\
\hline
\end{tabular}




\begin{tabular}{|c|c|c|c|}
\hline S/NO & Title & Authors & $\begin{array}{llll}\text { Major findings } & \text { (Constraints facing } \\
\text { SMEs) } & & & \\
\end{array}$ \\
\hline 11 & $\begin{array}{l}\text { The Lack of Business Dispute } \\
\text { Resolution in East Africa: An } \\
\text { Unresolved Impediment to SME } \\
\text { Development? }\end{array}$ & (Tillmar, 2016) & $\begin{array}{l}\text { Lack of access to finance, corruption and a } \\
\text { lack of business training. }\end{array}$ \\
\hline 12 & $\begin{array}{l}\text { Challenges to Entrepreneurship } \\
\text { Development in Tanzania }\end{array}$ & $\begin{array}{l}\text { (Isaga \& } \\
\text { Musabila, 2017) }\end{array}$ & The motivation of the business owners. \\
\hline 13 & $\begin{array}{lrr}\text { Factors } & \text { Affecting Small \& } \\
\text { Medium } & \text { Enterprises } \quad \text { (SMEs) } \\
\text { Startup and Growth in Tanzania }\end{array}$ & (Anderson, 2017) & $\begin{array}{l}\text { Inborn individual attributes, changing } \\
\text { business environments, competitive } \\
\text { activities and location, inadequate finance, } \\
\text { inadequate human and social resources, and } \\
\text { a lack of technical and management skills. }\end{array}$ \\
\hline 14 & $\begin{array}{l}\text { Financial Barriers and How to } \\
\text { Overcome Them: The Case of } \\
\text { Women Entrepreneurs in Tanzania }\end{array}$ & (Lindvert, 2017) & Lack of capital. \\
\hline 15 & $\begin{array}{l}\text { Social Capital In Selected } \\
\text { Business Associations Of Food } \\
\text { Processing SMEs In Tanzania And } \\
\text { Rwanda: A Synthetic Based } \\
\text { Approach }\end{array}$ & (Gamba, 2017) & Lack of social capital. \\
\hline 16 & $\begin{array}{l}\text { Challenges to Entrepreneurship } \\
\text { Development in Tanzania }\end{array}$ & $\begin{array}{l}\text { (Isaga \& } \\
\text { Musabila, 2017) }\end{array}$ & The motivation of the business owners. \\
\hline 17 & $\begin{array}{l}\text { Social-Economic Constraints } \\
\text { towards Women Business Growth } \\
\text { in Tanzania }\end{array}$ & $\begin{array}{l}\text { (Nyangarika, } \\
2017 \text { ) }\end{array}$ & $\begin{array}{l}\text { Poor access to market information, } \\
\text { technology and finance, poor linkages with } \\
\text { support services, and an unfavourable } \\
\text { policy and regulatory environment. }\end{array}$ \\
\hline 18 & $\begin{array}{l}\text { A structuration analysis of Small } \\
\text { and Medium Enterprise (SME) } \\
\text { adoption of E-Commerce: The } \\
\text { case of Tanzania }\end{array}$ & $\begin{array}{ll}\text { (Kabanda } & \& \\
\text { Brown, 2017) } & \end{array}$ & Poor technology adoption. \\
\hline 19 & $\begin{array}{l}\text { Microfinance Traps and Relational } \\
\text { Exchange Norms: A Field Study of } \\
\text { Women Entrepreneurs in Tanzania }\end{array}$ & $\begin{array}{l}\text { (Lindvert et al., } \\
\text { 2018) }\end{array}$ & Lack of access to capital. \\
\hline 20 & $\begin{array}{l}\text { Start-up motives and challenges } \\
\text { facing female entrepreneurs in } \\
\text { Tanzania }\end{array}$ & (Isaga, 2019) & $\begin{array}{l}\text { Lack of access to finance, gender-related } \\
\text { problems and social and cultural } \\
\text { commitments. }\end{array}$ \\
\hline 21 & $\begin{array}{l}\text { SME Globalization-Tanzania Case } \\
\text { Study }\end{array}$ & $\begin{array}{l}\text { (Juma } \& \text { Said, } \\
\text { 2019) }\end{array}$ & $\begin{array}{l}\text { Bureaucracy, poor Physical infrastructures, } \\
\text { inferior products, poor services, inadequate } \\
\text { business training and skills, little access to } \\
\text { information and limited admission to } \\
\text { technological developments, Marketing } \\
\text { difficulties, a lack of business training and } \\
\text { inadequate business skills. }\end{array}$ \\
\hline
\end{tabular}

Source: Literature Review (2019) 


\subsection{Conceptual Framework}

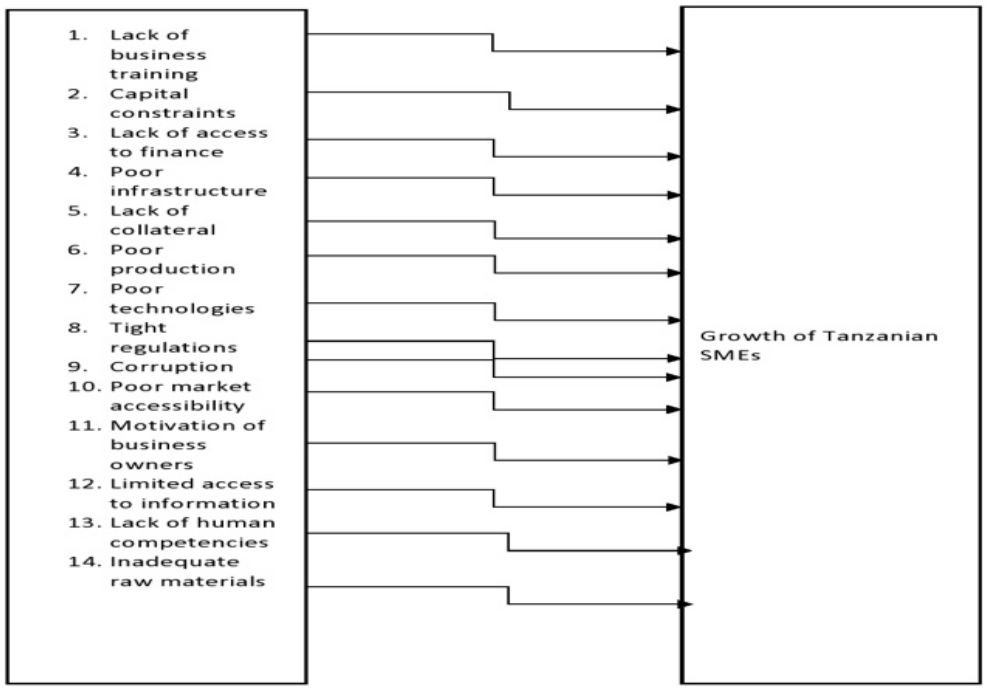

Figure 1: Conceptual framework

\subsection{Hypotheses}

$\mathrm{H} 1$ : There is a negative relationship between a lack of business training and SME growth in Tanzania

H2: There is a negative relationship between capital constraints and SME growth in Tanzania

H3: There is a negative relationship between a lack of access to finance and SME growth in Tanzania

$\mathrm{H} 4$ : There is a negative relationship between poor infrastructure and SME growth in Tanzania

H5: There is a negative relationship between a lack of collateral and SME growth in Tanzania

H6: There is a negative relationship between poor production and SME growth in Tanzania

H7: There is a negative relationship between poor technologies and SME growth in Tanzania

H8: There is a negative relationship between tight regulations and SME growth in Tanzania

H9: There is a negative relationship between corruption and SME growth in Tanzania

H10: There is a negative relationship between poor market accessibility and SME growth in Tanzania

H11: There is a negative relationship between the motivation of the business owners and SME growth in Tanzania

H12: There is a negative relationship between a limited access to information and SME growth in Tanzania

H13: There is a negative relationship between a lack of human competencies and SME growth in Tanzania

H14: There is a negative relationship between inadequate raw materials and SME growth in Tanzania

\section{Research Methodology}

A mixed-method approach was adopted in this study where content analysis and descriptive statistics were used. First, content analysis was employed by the researchers by reviewing 21 recent items of literature from within the last 5 years on SMEs in Tanzania. Next, a descriptive analysis was conducted whereby frequencies and percentages were used to determine the most significant factors impacting SME growth. A sample size of 21 literature items was deemed to be suitable for this study. Mashenene \& Rumanyika (2014) recommended that a minimum of 12 literature items is sufficient to conduct analysis and draw conclusions. In this study, 14 variables were extracted and analysed using frequencies and percentages, and these were presented in tabular form. The variables extracted in the study include (i) Lack of business training (LBT), (ii) Capital constraints (CC), (iii) Lack of access to finance (LAF), (iv) Poor infrastructure (PI), (v) Lack of collateral (LOC), (vi)Poor production (PP),(vii) Poor technologies (PT), (viii) Tight regulations (TR), (ix) Corruption (CO), (x) Poor market accessibility (PMA), (xi) Motivation of business owners (MOB), (xii) Limited access to information (LI), (xiii) Lack of human competencies (LHC) and (xiv)Inadequate raw materials (IRM). 


\section{Findings}

Table 2. Business impediments affecting SME growth

\begin{tabular}{|c|c|c|c|c|c|c|c|c|c|c|c|c|c|c|c|}
\hline $\mathrm{S} / \mathrm{N} 0$ & $\begin{array}{l}\text { Article } \\
\text { researcher }\end{array}$ & LBT & $\mathrm{CC}$ & LAF & PI & LOC & $\mathrm{PP}$ & $\mathrm{PT}$ & $\mathrm{TR}$ & $\mathrm{CO}$ & PMA & MOB & LI & $\mathrm{LHC}$ & IRM \\
\hline 1. & $\begin{array}{l}\text { (Mashenene \& } \\
\text { Rumanyika, } \\
\text { 2014) }\end{array}$ & $\mathbf{X}$ & $\mathbf{X}$ & & & & & & & & & & & & \\
\hline 1. & $\begin{array}{l}\text { (Makorere, } \\
\text { 2014) }\end{array}$ & $\mathbf{X}$ & $\mathbf{X}$ & $\mathbf{X}$ & $\mathbf{X}$ & & $\mathbf{X}$ & & & & & & & & $\mathbf{X}$ \\
\hline 2. & $\begin{array}{l}\text { (Mashenene, } \\
\text { Macha, \& } \\
\text { Donge, 2014) }\end{array}$ & & $\mathbf{X}$ & $\mathbf{X}$ & & $\mathbf{X}$ & & & & & & & & & \\
\hline 3. & $\begin{array}{l}\text { (Haselip, } \\
\text { Desgain \& } \\
\text { Mackenzie, } \\
\text { 2015) }\end{array}$ & & & & & & & & & & & & & $\mathbf{X}$ & \\
\hline 4. & $\begin{array}{l}\text { (Mashenene, } \\
\text { 2015) }\end{array}$ & & & $\mathbf{X}$ & & $\mathbf{X}$ & & & $\mathbf{X}$ & $\mathbf{X}$ & & & & & \\
\hline 5. & $\begin{array}{l}\text { (Rumanyika, } \\
\text { 2015) }\end{array}$ & & & & $\mathbf{X}$ & & & $\mathbf{X}$ & & & & & & & \\
\hline 6. & $\begin{array}{l}\text { (Kimathi, } \\
\text { 2015) }\end{array}$ & & & $\mathbf{X}$ & & & & & & & & & & & \\
\hline 7. & $\begin{array}{l}\text { (Mpunga, } \\
\text { 2016) }\end{array}$ & & $\mathbf{X}$ & & & & $\mathbf{X}$ & $\mathbf{X}$ & $\mathbf{X}$ & & & & $\mathbf{X}$ & & \\
\hline 8. & $\begin{array}{l}\text { (Magasi, } \\
\text { 2016) }\end{array}$ & & & & & & & & & & & & & & \\
\hline 9. & $\begin{array}{l}\text { (Ekblom, } \\
\text { 2016) }\end{array}$ & & $\mathbf{X}$ & & & & & & $\mathbf{X}$ & & $\mathbf{X}$ & & & & $\mathbf{X}$ \\
\hline 10. & $\begin{array}{l}\text { (Tillmar, } \\
\text { 2016) }\end{array}$ & $\mathbf{X}$ & & $\mathbf{X}$ & & & & & & $\mathbf{X}$ & & & & & \\
\hline 11. & $\begin{array}{ll}\text { Isaga \& } \\
\text { Musabila, } \\
\text { 2017) }\end{array}$ & & & & & & & & & & & $\mathbf{X}$ & & & \\
\hline 12. & $\begin{array}{l}\text { (Anderson, } \\
\text { 2017) }\end{array}$ & & & $\mathbf{X}$ & & & & & & & & & & $\mathbf{X}$ & \\
\hline 13. & $\begin{array}{l}\text { (Lindvert, } \\
\text { 2017) }\end{array}$ & & $\mathbf{X}$ & & & & & & & & & & & & \\
\hline 14. & (Gamba, 2017) & & & & & & & & & & & & & & \\
\hline 15. & $\begin{array}{ll}\text { Isaga } \quad \& \\
\text { Musabila, } \\
\text { 2017) }\end{array}$ & & & & & & & & & & & $\mathbf{X}$ & & & \\
\hline 16. & $\begin{array}{l}\text { (Nyangarika, } \\
\text { 2017) }\end{array}$ & & & $\mathbf{X}$ & & & & $\mathbf{X}$ & $\mathbf{X}$ & & $\mathbf{X}$ & & $\mathbf{X}$ & & \\
\hline 17. & $\begin{array}{l}\text { Kabanda \& } \\
\text { Brown, 2017) }\end{array}$ & & & & & & & $\mathbf{X}$ & & & & & & & \\
\hline 18. & $\begin{array}{l}\text { Lindert et al., } \\
\text { 2018) }\end{array}$ & & $\mathbf{X}$ & & & & & & & & & & & & \\
\hline 19. & (Isaga, 2019) & & & $\mathbf{X}$ & & & & & & & & & & & \\
\hline 20. & $\begin{array}{l}\text { (Juma \& Said, } \\
\text { 2019) }\end{array}$ & $\mathbf{X}$ & & & $\mathbf{X}$ & & & $\mathbf{X}$ & $\mathbf{X}$ & & $\mathbf{X}$ & & $\mathbf{X}$ & $\mathbf{X}$ & \\
\hline
\end{tabular}

(Source Literature review 2019)

Keys

1. Lack of business training (LBT)

2. Capital constraints (CC)

3. Lack of access to finance (LAF)

4. Poor infrastructure (PI)

5. Lack of collateral (LOC)

6. Poor production (PP)

7. Poor technologies (PT)

8. Tight regulations (TR)

9. Corruption (CO)

10. Poor market accessibility (PMA)

11. Motivation of business owners (MOB)

12. Limited access to information (LI)

13. Lack of human competencies (LHC)

14. Inadequate raw materials (IRM)

Based on the table above, the most extracted variables have been presented as frequencies and percentages (frequency divided by literature). 
Table 3. Results of the SME growth constraints

\begin{tabular}{|l|l|l|}
\hline Variable & Frequency & Percentage \% \\
\hline Lack of business training & 4 & 19 \\
\hline Capital constraints & 7 & 332 \\
\hline Lack of access to finance & 8 & 382 \\
\hline Poor infrastructure & 3 & 14 \\
\hline Lack of collateral & 2 & 10 \\
\hline Poor production & 2 & 10 \\
\hline Poor technologies & 5 & 247 \\
\hline Tight regulations & 5 & 248 \\
\hline Corruption & 2 & 10 \\
\hline Poor market accessibility & 3 & 14 \\
\hline Motivation of business owners & 2 & 10 \\
\hline Limited access to information & 3 & 14 \\
\hline Lack of human competencies & 3 & 14 \\
\hline Inadequate raw materials & 2 & 10 \\
\hline
\end{tabular}

Source Literature Review (2019)

From the table above, its shows that a lack of access to finance has the most negative relationship with the growth of SMEs by $38 \%$. This proves that most SMEs fail to grow due to financial constraints. This is followed by capital constraints (CC) at 33\%. This demonstrates that SMEs fail to grow due to being underfunded to reach their initial business goals as set at the beginning of the business. Next to CC, both poor technology and tight regulations scored $24 \%$ as the variables affecting the growth of SMEs. Other factors limiting SME growth include a lack of business training at $19 \%$, poor infrastructure, market accessibility, limited access to information and a lack of human competencies with a similar score of $14 \%$ and inadequate raw materials, corruption, a lack of collateral and the motivation of business owners which scored $10 \%$ in terms of their negative effect on SMEs growth.

\section{Discussion of the findings}

The findings reveal that the four significant variables affecting SCM growth are financial constraints, capital constraints, poor technology and tight regulations. This finding indicates that hypotheses 2, 3, 7 and 8 are significant and have been accepted. This indicates that Tanzanian SMEs fail to grow due to issues in finance, capital, poor technology and tight regulations that are imposed by the government. The results are in line with those of Mashenene \& Rumanyika (2014) who found that both capital constraints and business training significantly affect SME growth in Tanzania. These findings also echo those of Nyangarika (2017) who reported that finance, technological market accessibility and an unfavourable regulatory environment are the factors standing in the way of SME growth. Moreover, these findings are incongruent with those of Juma \& Said (2019) who found that marketing difficulties, a lack of business training, inadequate business skills poor infrastructure and technological difficulties are the main impediments to SME growth.

\section{Conclusion and recommendations}

The purpose of this paper was to evaluate the constraints affecting the growth of SMEs in Tanzania. The paper concludes that financial constraints, capital constraints, poor technology and tight regulations to be the most significant impediments to SME growth in Tanzania. These findings imply that financial institutions in Tanzania like banks and microfinance institutions should provide financial assistance through improving their borrowing procedures by lowering the rates and collateral. This is as SMEs are unable to afford collateral which stands in the way of them gaining financial assistance. Mashenene (2015) recommends that simplifying the lending schemes by removing the tight borrowing regulations is vital for easier accessibility to credit by SMEs. The same has been suggested by Lindvert (2017) who found that discriminatory borrowing loans leads to SME growth failure as adequate finance is not issued by banks. Additionally, the government of Tanzania should provide support to SMEs by levying the rules and regulations to allow SMEs to grow. Shamsuddin et al. (2017) reported there to be a positive relationship between support from the government and SME performance and growth.

SIDO should offer business training to SMEs to enable them to gain new business knowledge and to change their way of thinking. Mashenene \& Rumanyika (2014) suggest that business training can enable the SMEs to overcome challenges such as technological difficulties, corruption and fear of competition.

Future researchers should focus on how these issues affect SME growth individually by conducting primary data collection and analysis. It will be interesting to conduct a comparative study on the growth impediments to SMEs in developed and developing nations. 


\section{Acknowledgements}

The authors would like to thank the staff at UWS for their encouragement and support to write this paper. We would like to thank all of our family members for their caring support throughout conducting this research.

\section{References}

Anderson, W. (2017). Factors Affecting Small \& Medium Enterprises (SMEs) Start- up and Growth in Tanzania. The Pan-African Journal of Business Management, [online] 1(1), pp.1-51.

Baporikar, N., Nambira, G. \& Gomxos, G. (2016). Exploring factors hindering SMEs' growth: evidence from Nambia. Journal of Science and Technology Policy Management, [online] 7(2), pp.190-211.

Bilal, A., Khan, A. \& Akoorie, M. (2016). Constraints to growth: a cross country analysis of Chinese, Indian and Pakistani SMEs. Chinese Management Studies, [online] 10(2), pp.365-386.

Bouazza, A., Ardjouman, D. \& Abada, O. (2015). Establishing the Factors Affecting the Growth of Small and Medium-sized Enterprises in Algeria. American International Journal of Social Science, 4(2), pp.101-156.

Clegg, B. (2018). Perceptions of growth-impeding constraints acting upon SMEs' operations and the identification and use of transitionary paths to elevate them. International Journal of Operations \& Production Management, 38(3), pp.756-783.

Ekblom, M. (2016). Challenges Facing Food Processing MSEs in Tanzania: A Qualitative Case Study of the Sunflower Oil Industry in Babati, Manyara. [online] DIVA. Available at: http://www.divaportal.org/smash/record.jsf?pid=diva2\%3A935700\&dswid=1978 [Accessed 24 Oct. 2019].

Gamba, F. (2017). Social Capital in Selected Business Associations of Food Processing SMEs in Tanzania and Rwanda: A Synthetic Based Approach. International Journal of Asian Social Science, 7(1), pp.63-84.

Haselip, J., Desgain, D. \& Mackenzie, G. (2015). Non-financial constraints to scaling-up small and medium-sized energy enterprises: Findings from field research in Ghana, Senegal, Tanzania and Zambia. Energy Research \& Social Science, 5, pp.78-89.

Isaga, N. (2019). Start-up motives and challenges facing female entrepreneurs in Tanzania. International Journal of Gender and Entrepreneurship, 11(2), pp.102-119.

Isaga, N. \& Musabila, A. (2017). Challenges to Entrepreneurship Development in Tanzania. Entreprenuership in Africa, 15.

Juma, S. \& Said, F. (2019). SME Globalization-Tanzania Case Study. International Journal Advances in Social Science and Humanities, 4(6).

Kabanda, S. \& Brown, I. (2017). A structuration analysis of Small and Medium Enterprise (SME) adoption of ECommerce: The case of Tanzania. Telematics and Informatics, 34(4), pp.118-132.

Kimathi, F. (2015). The Challenges Confronting Small Scale Businesses in accessing Microfinance Services from MFIs Case Study: Rural Tanzania. International Journal of Academic Research in Business and Social Sciences, 5(11), pp.299-311.

Lindvert, M. (2017). Financial Barriers and How to Overcome Them: The Case of Women Entrepreneurs in Tanzania. Entreprenuership in Africa, [online] 15. Available at: https://doi.org/10.1163/9789004351615 016 [Accessed 24 Oct. 2019].

Lindvert, M., Patel, P., Smith, C. \& Wincent, J. (2018). Microfinance Traps and Relational Exchange Norms: A Field Study of Women Entrepreneurs in Tanzania. Journal of Small Business Management,57(1), pp.230254

Magasi, C. (2016). Factors Influencing Business Succession Planning among SMEs in T anzania. European Journal of Business and Management, 8(3), pp.126-135.

Makorere, R. (2014). The role of microfinance in promoting small and medium enterprises (SMEs) in Tanzania: empirical evidence from SMEs holder who have received microcredit from financial institutions in Morogoro. Global Business and Economics Research Journal, 3(4), pp.1-19.

Mashenene, R. (2015). Proceedings of the Second European Academic Research Conference on Global Business, Economics, Finance and Banking. In: EAR15Swiss Conference. Zurich-Switzerland: Global biz research.

Mashenene, R. \& Rumanyika, J. (2014). Business Constraints and Potential Growth of Small and Medium Enterprises in Tanzania: A Review. European Journal of Business and Management, [online] 6(3), pp.72-79.

Mashenene, R., Macha,, J. \& Donge, L. (2014). Socio-Cultural Determinants and Enterprise Financial Sources among the Chagga and Sukuma Small and Medium Enterprises in Tanzania. International Review of Research in Emerging Markets and the Global Economy (IRREM), [online] 1(5), pp.265-283.

Mpunga, H. (2016). Examining the factors affecting export performance for Small and Medium Enterprises (SMEs) in Tanzania. Journal of Economics and Sustainable Development, [online] 7(6), pp.41-51.

Nyangarika, A. (2017). Social-Economic Constraints towards Women Business Growth in Tanzania. European Journal of Business and Management, 8(5), pp.130-139.

Rumanyika, J. (2015). Obstacles Towards Adoption Of Mobile Banking In Tanzania: A Review. International Journal of Information Technology and Business Management, 3(1), pp.1-17. 
Shamsuddin, J., Sarkawi, M., Jaafar, A. \& Rahim, N. (2017). Malaysian SMEs Performance and the Government Business Support Service: The Moderating Effects of Absorptive Capacity. Int. J Sup. Chain. Mgt, 6(4), pp.326-331.

Tillmar, M. (2016). The Lack of Business Dispute Resolution in East Africa: An Unresolved Impediment to SME Development? In: L. Achtenhagen and E. Brundin, ed., Entrepreneurship and SME Management Across Africa. Singapore: Springer.

Wang, Y. (2016). What are the biggest obstacles to the growth of SMEs in developing countries? - An empirical evidence from an enterprise survey. Borsa Istanbul Review, 16(3), pp.167-176.

World Bank Blogs. (2017). Improving access to finance for SMEs in Tanzania: Learning from Malaysia'sexperience.[online]Availableat:https://blogs.worldbank.org/eastasiapacific/improving-accessfinance-smes-tanzania-learning-malaysia-s-experience [Accessed 22 Oct. 2019].

Yukhanaev, A., Fallon, G., Baranchenko, Y. \& Anisimova, A. (2015). An Investigation into the Formal Institutional Constraints that Restrict Entrepreneurship and SME Growth in Russia. Journal of East-West Business,21(4), pp.313-341. 